\title{
Phytoplankton pigments and growth rates, and microzooplankton grazing in a large temperate estuary
}

\author{
George B. McManus ${ }^{1}$, Melissa C. Ederington-Cantrell ${ }^{2}$ \\ 'Marine Environmental Sciences Consortium, PO Box 369, Dauphin Island, Alabama 36528, USA, \\ and Department of Marine Sciences, University of South Alabama, Mobile, Alabama 36688, USA \\ ${ }^{2}$ Chesapeake Biological Laboratory, PO Box 38, Solomons, Maryland 20688, USA
}

\begin{abstract}
We used the dilution method to measure phytoplankton growth and microzooplankton grazing at 2 stations in Chesapeake Bay, USA, during spring, summer, and fall. Differential growth among phytoplankton taxa and selectivity of microzooplankton grazing were evaluated through the measurement of taxon-specific pigments. Some taxa showed consistently high growth rates (e.g. zeaxanthin, an indicator of cyanobacteria, always exceeded chlorophyll a in growth, ranging up to $2.52 \mathrm{~d}^{-1}$ ), while others varied widely. Across all experiments and pigments, microzooplankton grazing was correlated with phytoplankton growth rates and was significant in the removal of phytoplankton biomass, often equalling or exceeding growth estimates.
\end{abstract}

\section{INTRODUCTION}

Chesapeake Bay, USA, is a partially-mixed, highly productive estuary (Boynton et al. 1982). Persistent and recurrent hypoxia in its sub-pycnocline waters has prompted numerous investigations in recent years into the production and cycling of organic matter in the bay, especially into the fate of phytoplankton and anthropogenic nutrients (e.g. Officer et al. 1984, Malone et al. 1986, 1988, 1991, Nixon 1987, Tuttle et al. 1987).

The bay's annual cycles of phytoplankton biomass and production are out of phase. The biomass peak occurs with high freshwater discharge and increased day length in early spring, but the productivity peak occurs during summer, when the water column is most strongly stratified. Generally, the spring bloom is dominated by diatoms and other large phytoplankton and the summer is dominated by pico- and nanoplankton. A smaller bloom, associated with water column turnover, usually occurs in the fall (Van Valkenburg et al. 1978, Malone et al. 1986, 1988, Marshall \& Lacouture 1986, Sellner \& Kachur 1987).
Although the occurrence of deep-water hypoxia over large areas of the bay bottom in summer suggests that the fate of a significant fraction of the bay's phytoplankton production is to sink and decompose, little is known about the importance of grazing. What evidence there is suggests that larger zooplankton are usually not the main sink for phytoplankton biomass. For example, Sellner \& Kachur (1987) estimated that zooplankton $>73 \mu \mathrm{m}$ were only significant grazers in summer, and even then their grazing rates rarely exceeded $50 \%$ of standing stocks per day. Roman et al. (1988) reported daily rates of ca 1 to $7 \%$ of standing stocks grazed by $>200 \mu \mathrm{m}$ zooplankton in the mid-bay region during spring and summer. Few measurements of microzooplankton grazing have been published, but based on abundance estimates it is probably more significant than macrozooplankton in remineralizing phytoplankton biomass (Brownlee \& Jacobs 1987).

We studied phytoplankton community composition and grazing mortality in Chesapeake Bay during 3 contrasting periods: spring, in the latter stages of the annual diatom bloom; summer, the time of maximum 
productivity; and fall, when density stratification had begun to break down. Our focus was on microzooplankton grazing. Grazing by these smallest zooplankton serves to retain material in the upper water column because, unlike larger grazers, they do not produce sinking fecal pellets and thus contribute less to the vertical flux of material that fuels hypoxia. Our goal was to measure microzooplankton grazing rates in contrasting seasons and at 2 disparate stations, to compare grazing to phytoplankton growth rates, and to evaluate grazing selectivity by quantifying taxonspecific phytoplankton pigments.

\section{METHODS}

Cruises were made during April, May, August, and October 1990. In April, May and August, 2 stations were sampled: one in the upper, oligohaline region of the bay (Stn N3; 39 $20.9^{\prime} \mathrm{N}, 76^{\circ} 10.9^{\prime} \mathrm{W}$ ) and one in the middle, mesohaline region (Stn $B M 7 ; 38^{\circ} 28.3^{\prime} \mathrm{N}$, $76^{\circ} 22.5^{\prime} \mathrm{W}$ ). In October, only the mesohaline was sampled, and at a station $11 \mathrm{~km}$ southeast of the earlier one ( $\mathrm{Stn} \mathrm{HI} ; 38^{\circ} 15.4^{\prime} \mathrm{N}, 76^{\circ} 15.0^{\prime} \mathrm{W}$ ). All stations were in the central channel.

We used the dilution method of Landry \& Hassett (1982) to estimate growth and grazing mortality of phytoplankton. For each experiment, water was collected from the surface in Niskin bottles, screened through $202 \mu \mathrm{m}$ nitex mesh, and pooled into an opaque, $50 \mathrm{l}$ polyethylene carboy. Subsamples were taken for nutrient analysis (Parsons et al. 1984). Usually, water was collected before first light and filtered (HA Millipore, $0.45 \mu \mathrm{m}$ pore size, $142 \mathrm{~mm}$ diameter) to make the diluent. Later in the morning, a second sample was taken for the grazing measurements. For some experiments, a single sample was taken and it was kept dark and at near-ambient temperature while diluent was made $(<1 \mathrm{~h})$. Dilution series were prepared with $0,35,70,85$, and $95 \%$ filtered seawater in duplicate 21 polycarbonate bottles. We did not routinely add nutrients to the samples, but on 2 occasions we ran a parallel dilution series with ammonium and phosphate supplements $\left(5 \mu \mathrm{M} \mathrm{NH}{ }_{4} \mathrm{Cl}\right.$ and $1 \mu \mathrm{M}$ $\mathrm{NaH}_{2} \mathrm{PO}_{4}$, respectively). Bottles were incubated for $24 \mathrm{~h}$ in a deck incubator with surface running seawater for temperature control. The incubator was covered with one layer of neutral density screening (passing about $50 \%$ of incident radiation) except for the August experiments, which received full sunlight. Phytoplankton net growth rates were calculated from changes in chlorophylls and other pigments, assuming exponential growth (Landry \& Hassett 1982, Gallegos 1989). Our dilution curves often indicated saturated feeding for the microzooplankton (Fig. 1). To account

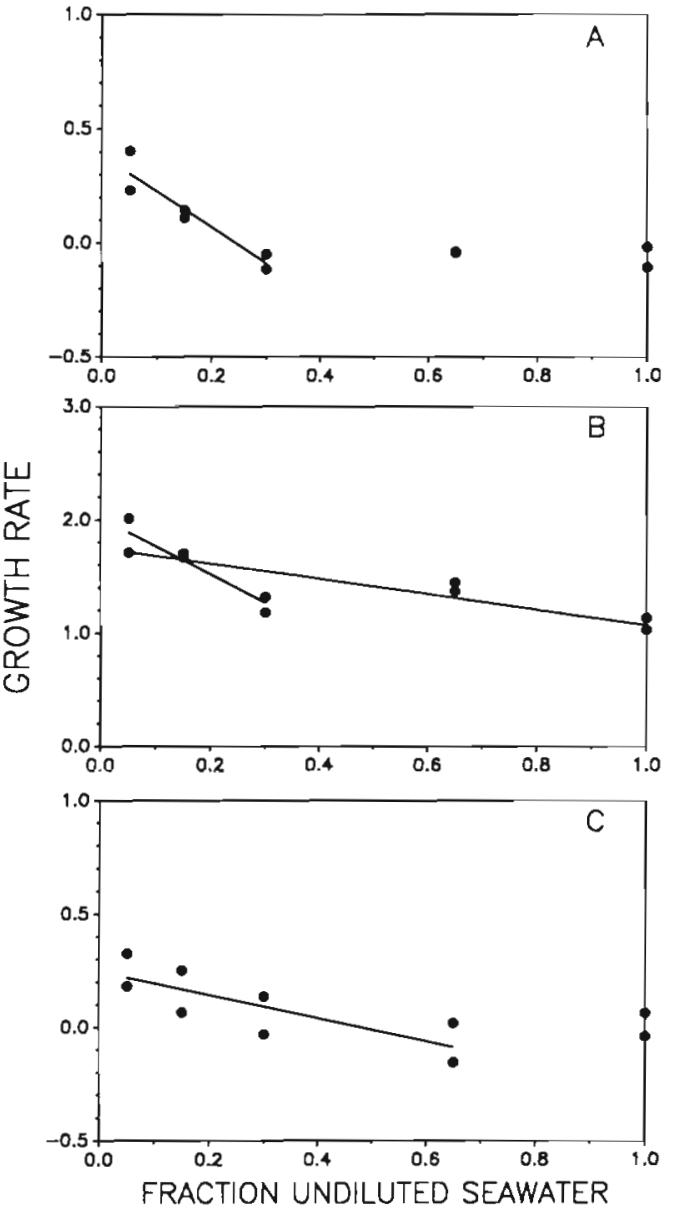

Fig. 1. Phytoplankton net growth rate $\left(\mathrm{d}^{-1}\right)$, as chl $a_{\text {, vs }}$ fraction undiluted seawater for 3 experiments that showed evidence of saturated feeding. Lines are least squares regressions for (A) 3 most dilute treatments, 17 May; (B) 3 most dilute treatments and all treatments (shallower line), 14 August; and (C) all dilutions (undiluted treatment omitted), 15 August

for this, we used the '3-point' method of Gallegos (1989) to estimate growth. With this method, only the most dilute treatments are used to extrapolate for phytoplankton growth at infinite dilution (the $y$-intercept of a standard dilution curve). We also accounted for microzooplankton growth in the incubations using his method (Eq. 11 in Gallegos 1989).

Pigments were extracted from phytoplankton collected on Whatman glass fiber filters $(\mathrm{GF} / \mathrm{F})$ in $100 \%$ acetone, and separated and quantified by absorbance using high performance liquid chromatography (HPLC). We followed the protocols of Mantoura \& Llewellyn (1983), except that we used 20:80 (by volume) of $1 \mathrm{M}$ ammonium acetate:methanol as solution $A$, and we ran for $40 \mathrm{~min}$ rather than 20 , with a gradient from $100 \%$ A to $100 \%$ B $(40: 60$, acetone:methanol) in $25 \mathrm{~min}, 15 \mathrm{~min}$ at $100 \% \mathrm{~B}$, and 


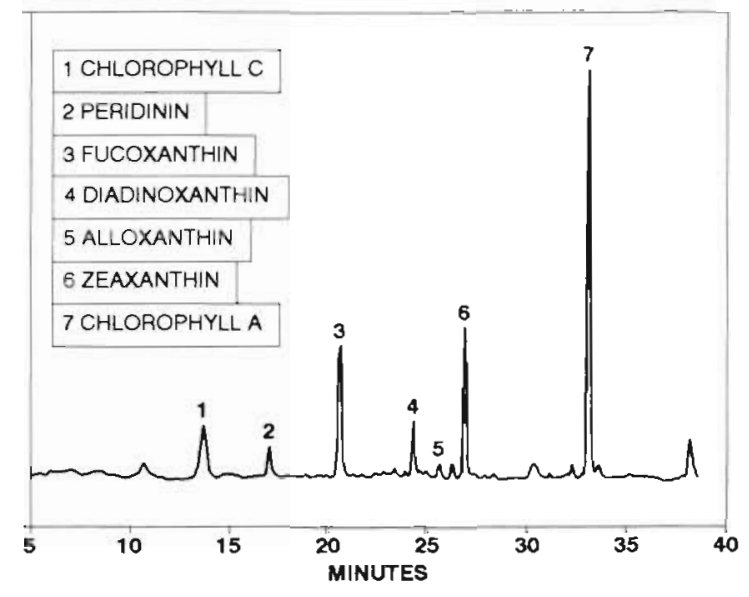

Fig. 2. Typical chromatogram, showing pigment markers used in this study. Sample was from August, mid-bay

5 min to re-equilibrate the column to initial conditions. A typical chromatogram is shown in Fig. 2. The system was initially standardized with pure standards of carotenoids fraction-collected from various phytoplankton cultures and quantified spectrophotometrically. Response factors relative to chlorophyll a (chl a) were calculated for our particular gradient system and detector, and routine calibrations were done with pure chl $a$, obtained from Sigma Chemical Co. A mixed standard of 14 known carotenoids and chlorophylls was used to verify retention times regularly. When chl $b$ was abundant, we ran some samples with the solvent system of Wright \& Shearer (1984) to separate lutein from zeaxanthin.

For all experiments except 10 and 11 April and 16 May, we estimated the abundance of ciliates, one of the dominant microzooplankton groups in the bay, at $t=0 \mathrm{~h}$ and $t=24 \mathrm{~h}$ in one or both of the undiluted treatments. Ciliates (not including the phototroph Myrionecta rubrum) were enumerated from glutaraldehyde-preserved samples by concentrating 100 to $200 \mathrm{ml}$ volumes by settling in 2 stages and counting in a Sedgewick-Rafter cell. At least 100 individuals were counted in each sample. Where duplicate undiluted treatments were both counted, the coefficient of variation averaged $7 \%(n=5)$ between counts.

\section{RESULTS}

The mid-bay station, which was $17 \mathrm{~m}$ deep, was salinity-stratified in April, May and August (top-tobottom salinity difference 6.5 to $10.5 \%$; Table 1). In October the salinity difference was only $2.8 \%$, consistent with the breakdown of stratification annually caused by fall storms. Salinity stratification in the mesohaline region is forced by the gravitational circulation, but the water column stratifies and destratifies episodically, depending on storms, from early fall through early spring (Malone et al. 1986, Goodrich et al. 1987). The upper bay station ( $8 \mathrm{~m}$ deep) was vertically homogeneous, $0.1 \%$ in April and May, and 4 to $5 \%$ in August.

At both stations, nitrate plus nitrite often exceeded $10 \mu \mathrm{M}$, and total dissolved inorganic nitrogen (ammonium + nitrate + nitrite) was never less than $2.5 \mu \mathrm{M}$ on any date at either station (Table 1). Phosphate ranged from 0.03 to $0.40 \mu \mathrm{M}$.

Except in April at the mid-bay station, most of the chlorophyll was in the nanoplankton $(<20 \mu \mathrm{m})$ size fraction. Although we did not make microscopic counts of the phytoplankton, based on historical data the larger size fraction in April was probably mostly chainforming diatoms and larger dinoflagellates from the annual spring bloom.

Table 1. Hydrographic and nutrient data. Nutrient concentrations are in $\mu \mathrm{M}$. For size-fractionation, phytoplankton was collected on glass fiber filters and chlorophyll measured fluorometrically in whole water samples and in samples pre-screened through $20 \mu \mathrm{m}$ nylon mesh (Parsons et al. 1984; data provided by T. Malone). ND: not determined

\begin{tabular}{|c|c|c|c|c|c|c|c|c|c|}
\hline \multirow[t]{2}{*}{ Date } & \multirow[t]{2}{*}{ Station } & \multirow[t]{2}{*}{ Location } & \multirow{2}{*}{$\begin{array}{l}\mathrm{T}\left({ }^{\circ} \mathrm{C}\right) \\
\text { Surface }\end{array}$} & \multicolumn{2}{|c|}{ S $(\%)$} & \multirow{2}{*}{$\begin{array}{c}\mathrm{NH}_{4} \\
\text { Surface }\end{array}$} & \multirow{2}{*}{$\begin{array}{c}\mathrm{NO}_{3}+\mathrm{NO}_{2} \\
\text { Surface }\end{array}$} & \multirow{2}{*}{$\begin{array}{c}\mathrm{PO}_{4} \\
\text { Surface }\end{array}$} & \multirow{2}{*}{$\begin{array}{c}\text { Chl a } \\
(\%<20 \mu \mathrm{m})\end{array}$} \\
\hline & & & & Surface & Bottom & & & & \\
\hline $11 \mathrm{Apr}$ & N3 & Upper bay & 9.8 & 0.1 & 0.1 & 2.02 & 105.00 & 0.16 & 92 \\
\hline 16 May & N3 & Upper bay & 17.6 & 0.1 & 0.1 & 4.10 & 68.90 & 0.11 & 86 \\
\hline $14 \mathrm{Aug}$ & N3 & Upper bay & 26.0 & 4.2 & 5.4 & 8.07 & 40.00 & 0.40 & 93 \\
\hline $10 \mathrm{Apr}$ & $B M 7$ & Mid-bay & 9.2 & 10.7 & 20.7 & 2.27 & 38.40 & 0.07 & 48 \\
\hline $12 \mathrm{Apr}$ & BM7 & Mid-bay & 9.4 & 11.5 & 19.6 & 1.31 & 24.20 & 0.03 & 71 \\
\hline 17 May & BM7 & Mid-bay & 17.5 & 10.7 & 17.2 & 1.62 & 9.98 & 0.03 & 78 \\
\hline 15 Aug & BM7 & Mid-bay & 26.7 & 13.0 & 23.5 & 2.29 & 3.32 & 0.03 & 95 \\
\hline 16 Aug & BM7 & Mid-bay & 26.7 & 13.1 & 23.2 & 0.90 & 1.68 & 0.03 & 86 \\
\hline $30 \mathrm{Oct}$ & $\mathrm{HI}$ & Mid-bay & 15.3 & 13.3 & 16.1 & $2.20^{\mathrm{a}}$ & $9.58^{d}$ & $0.28^{\mathrm{a}}$ & ND \\
\hline
\end{tabular}


Table 2. Concentrations ( $\mu \mathrm{g}^{-1}$ ) of selected phytoplankton pigments. Station locations as in Table $1 ; \mathrm{n}=$ no. of replicate filters extracted. For the 5 replicates from October, coefficients of variation ranged from 4 to $12 \%$ among pigments

\begin{tabular}{|c|c|c|c|c|c|c|c|c|c|c|c|}
\hline Station & Date & $(n)$ & Chl a & Chl $b$ & $\mathrm{Chl} \mathrm{C}$ & Peridinin & $\begin{array}{c}\text { Fuco- } \\
\text { xanthin }\end{array}$ & $\begin{array}{c}\text { Diadino- } \\
\text { xanthin }\end{array}$ & $\begin{array}{c}\text { Allo- } \\
\text { xanthin }\end{array}$ & Lutein & Zeaxanthin \\
\hline N3 & $11 \mathrm{Apr}$ & (2) & 2.76 & 0.00 & 0.26 & 0.00 & 0.77 & 0.09 & 0.10 & 0.00 & 0.03 \\
\hline N3 & 16 May & (1) & 2.18 & 0.44 & 0.93 & 0.00 & 0.86 & 0.08 & 0.06 & 0.00 & 0.06 \\
\hline N3 & 14 Aug & (2) & 6.76 & 0.43 & 2.46 & 0.00 & 0.80 & 0.15 & 0.58 & 0.05 & 0.25 \\
\hline BM7 & $10 \mathrm{Apr}$ & (2) & 17.71 & 0.00 & 11.07 & 0.00 & 6.94 & 1.17 & 0.00 & 0.00 & 0.00 \\
\hline $\mathrm{BM} 7$ & $12 \mathrm{Apr}$ & (2) & 22.96 & 0.00 & 12.66 & 0.00 & 7.58 & 1.16 & 0.09 & 0.00 & 0.00 \\
\hline BM7 & 17 May & (1) & 19.47 & 0.00 & 8.33 & 0.00 & 3.26 & 0.49 & 0.06 & 0.00 & 0.00 \\
\hline BM7 & 15 Aug & (1) & 7.23 & 0.00 & 2.13 & 0.41 & 1.36 & 0.10 & 0.28 & 0.00 & 0.81 \\
\hline BM7 & 16 Aug & (2) & 11.31 & 0.30 & 5.50 & 1.01 & 2.05 & 0.32 & 0.25 & 0.00 & 0.74 \\
\hline $\mathrm{HI}$ & $30 \mathrm{Oct}$ & (5) & 13.82 & 0.31 & 8.79 & 0.76 & 2.04 & 0.59 & 1.65 & 0.05 & 0.08 \\
\hline
\end{tabular}

Data on concentrations of 9 selected pigments are summarized in Table 2. Chl a concentration was consistently higher at the mid-bay station. In keeping with the size fraction data, carotenoids associated with larger phytoplankton (e.g. fucoxanthin, diadinoxanthin) were more abundant in spring, while those asociated with nano-and picophytoplankton [e.g. alloxanthin (cryptophytes) and zeaxanthin (cyanobacteria)] were more abundant in summer and fall.

Results of the dilution experiments are summarized in Table 3. Not all pigments were detectable on all dates, especially in the $95 \%$ dilution treatment, so growth and grazing calculations are presented for a subset of the pigments listed in Table 2. Using chl a as an indicator of the whole phytoplankton community, growth rates ranged from 0 to $2.15 \mathrm{~d}^{-1}$. For some individual pigments, maximum growth rates were higher. For example, at the upper bay station in August, growth rates based on fucoxanthin were $2.91 \mathrm{~d}^{-1}(=4.2$ doublings $\mathrm{d}^{-1}$ ). In general, however, growth rates were $<1 \mathrm{~d}^{-1}$. For the mid-bay experiments that were not supplemented with nutrients, the chl a growth rate was $0.23 \mathrm{~d}^{-1}$ (= 0.33 doublings $\left.\mathrm{d}^{-1}\right)$ averaged over all dates $(\mathrm{SE}=0.05, \mathrm{n}=6)$. There was no obvious trend toward higher growth rates in the summer.

Phytoplankton grazing mortality (based on chl a) ranged from $<0$ to $1.6 \mathrm{~d}^{-1}$ For the mid-bay station, average grazing mortality was $0.24 \mathrm{~d}^{-1}$ ( $\mathrm{SE}=0.04$, $n=6$ ). As with the growth data, there was no obvious seasonal trend. Net ciliate growth rates, assuming exponential growth, averaged only $0.13 \mathrm{~d}^{-1}$, but varied widely ( $\mathrm{SE}=0.18, \mathrm{n}=8$ ), ranging from -0.73 to $0.78 \mathrm{~d}^{-1}$ (Table 3).

\section{DISCUSSION}

As might be expected in a body of water with large gradients in turbidity, water depth, and salinity, Chesapeake Bay supports diverse phytoplankton assemblages, with wide seasonal and spatial variations. Based on earlier studies, the less saline upper bay has relatively more chlorophytes and filamentous cyanobacteria, and the mid-bay region relatively more chrysophytes and cryptophytes. Although no one study has sampled the whole bay synoptically, a comparison of several phytoplankton studies supports these general trends. For example, Sellner (1983) found filamentous cyanobacteria to dominate phytoplankton abundance ( $>15 \%$ of total cells, July through December) in the Gunpowder River, a tributary of upper Chesapeake Bay. In the mid-bay region, on the other hand, Van Valkenburg et al. (1978) found filamentous cyanobacteria to be only a small component of the phytoplankton. McCarthy et al. (1974) found a decreasing chl $b$ :chl a ratio on a down-bay transect, suggesting a decreased contribution from chlorophytes with increasing salinity. Bay-wide, phytoplankton biomass is dominated by nanoplankton, except at the height of the spring bloom (McCarthy et al. 1974, Van Valkenburg et al. 1978, Sellner 1983).

We compared our results to these patterns observed by earlier workers. While microscopic examination reveals the most information about the taxonomic composition of phytoplankton assemblages, quantification of chlorophylls and carotenoid pigments can yield similar kinds of information with less manpower. The pigments we focused on range from the most broadly distributed (chl $a$, found in all phytoplankton) to those limited to a single taxon (e.g. alloxanthin, found only in cryptophytes). Some pigments are intermediate in their distributions and hence in their usefulness for chemotaxonomic studies of phytoplankton (Everitt et al. 1990). For example, peridinin is found only in dinoflagellates, but not in all dinoflagellates (Jeffrey 1980); fucoxanthin is found ubiquitously in diatoms, but also in chrysophytes and prymnesiophytes, which are morphologically and ecologically quite distinct from diatoms. With these caveats in mind, we compared 
Table 3. Growth and grazing rates $\left(\mathrm{d}^{-1}\right)$ for selected pigments and ciliates. SEs for growth are based on linear regressions of net growth rate vs fraction undiluted seawater for the 2 most dilute treatments [in duplicate, except where indicated (ND)]. For grazing, SE is based on 2 replicate estimates made using Eq. (11) from Gallegos (1989). Where ciliate growth was not estimated (NE), a value of zero was used in the equation

\begin{tabular}{|c|c|c|c|c|c|c|c|}
\hline Station & Date & Pigment & Growth & (SE) & Grazing & $(\mathrm{SE})$ & Ciliate growth \\
\hline N3 & $11 \mathrm{Apr}$ & $\begin{array}{l}\text { Chl a } \\
\text { Fucoxanthin }\end{array}$ & $\begin{array}{r}0.00 \\
-0.07\end{array}$ & $\begin{array}{l}(0.33) \\
(0.29)\end{array}$ & $\begin{array}{l}-0.22 \\
-0.14\end{array}$ & $\begin{array}{l}(0.09) \\
(0.05)\end{array}$ & $\mathrm{NE}$ \\
\hline N3 & 16 May & $\begin{array}{l}\text { Chl a } \\
\text { Chl } b \\
\text { Fucoxanthin } \\
\text { Diadinoxanthin } \\
\text { Alloxanthin } \\
\text { Zeaxanthin }\end{array}$ & $\begin{array}{r}2.15 \\
1.51 \\
0.95 \\
1.33 \\
-0.25 \\
2.52\end{array}$ & $\begin{array}{l}(0.05) \\
(0.11) \\
(0.04) \\
(0.02) \\
(0.11) \\
(0.02)\end{array}$ & $\begin{array}{r}0.76 \\
1.26 \\
-0.40 \\
-1.31 \\
-0.13 \\
1.46\end{array}$ & $\begin{array}{l}(0.03) \\
(0.05) \\
(0.06) \\
(0.12) \\
(0.06) \\
(0.03)\end{array}$ & NE \\
\hline N3 & $14 \mathrm{Aug}$ & $\begin{array}{l}\text { Chl a } \\
\text { Chl } b \\
\text { Chl } c \\
\text { Fucoxanthin } \\
\text { Diadinoxanthin } \\
\text { Alloxanthin }\end{array}$ & $\begin{array}{l}1.95 \\
1.24 \\
2.24 \\
2.91 \\
3.13 \\
0.47\end{array}$ & $\begin{array}{l}(0.15) \\
(0.09) \\
(0.28) \\
(0.16) \\
(0.12) \\
(0.14)\end{array}$ & $\begin{array}{l}1.60 \\
0.91 \\
1.78 \\
2.59 \\
2.55 \\
0.84\end{array}$ & $\begin{array}{l}(0.04) \\
(0.08) \\
(0.09) \\
(0.02) \\
(0.13) \\
(0.10)\end{array}$ & -0.57 \\
\hline BM7 & $10 \mathrm{Apr}$ & $\mathrm{Chl} \mathrm{a}$ & 0.21 & $(0.05)$ & 0.24 & $(0.03)$ & NE \\
\hline BM7 & $12 \mathrm{Apr}$ & $\begin{array}{l}\text { Chl a } \\
\text { Fucoxanthin } \\
\text { Alloxanthin }\end{array}$ & $\begin{array}{r}0.03 \\
-0.06 \\
2.23\end{array}$ & $\begin{array}{l}\text { ND } \\
\text { ND } \\
\text { ND }\end{array}$ & $\begin{array}{l}0.14 \\
0.11 \\
1.47\end{array}$ & $\begin{array}{l}\text { ND } \\
\text { ND } \\
\text { ND }\end{array}$ & -0.73 \\
\hline BM7 & $17 \mathrm{May}$ & $\begin{array}{l}\text { Chl a } \\
\text { Fucoxanthin } \\
\text { Alloxanthin } \\
\text { Diadinoxanthin } \\
\text { Peridinin }\end{array}$ & $\begin{array}{l}0.41 \\
0.38 \\
1.22 \\
0.56 \\
0.11\end{array}$ & $\begin{array}{l}(0.09) \\
(0.11) \\
(0.06) \\
(0.07) \\
(0.28)\end{array}$ & $\begin{array}{r}0.43 \\
0.43 \\
1.08 \\
0.54 \\
-0.09\end{array}$ & $\begin{array}{l}(0.03) \\
(0.03) \\
(0.03) \\
(0.04) \\
(0.20)\end{array}$ & 0.15 \\
\hline BM7 & $17 \mathrm{May}^{\mathrm{a}}$ & $\begin{array}{l}\text { Chl a } \\
\text { Fucoxanthin }\end{array}$ & $\begin{array}{l}0.34 \\
0.23\end{array}$ & $\begin{array}{l}(0.11) \\
(0.10)\end{array}$ & $\begin{array}{l}0.39 \\
0.38\end{array}$ & $\begin{array}{l}(0.06) \\
(0.02)\end{array}$ & 0.37 \\
\hline BM7 & 15 Aug & $\begin{array}{l}\text { Chl a } \\
\text { Fucoxanthin } \\
\text { Zeaxanthin } \\
\text { Diadinoxanthin }\end{array}$ & $\begin{array}{l}0.30 \\
0.45 \\
0.47 \\
0.85\end{array}$ & $\begin{array}{l}(0.12) \\
(0.24) \\
(0.22) \\
(0.23)\end{array}$ & $\begin{array}{r}0.20 \\
0.21 \\
-0.01 \\
0.23\end{array}$ & $\begin{array}{l}(0.02) \\
(0.03) \\
(0.01) \\
(0.03)\end{array}$ & 0.78 \\
\hline BM7 & $16 \mathrm{Aug}$ & $\begin{array}{l}\text { Chl a } \\
\text { Chl c } \\
\text { Zeaxanthin } \\
\text { Diadinoxanthin } \\
\text { Fucoxanthin } \\
\text { Alloxanthin } \\
\text { Peridinin }\end{array}$ & $\begin{array}{r}0.16 \\
0.78 \\
0.61 \\
0.58 \\
0.41 \\
0.45 \\
-0.95\end{array}$ & $\begin{array}{l}(0.07) \\
(0.18) \\
(0.06) \\
(0.16) \\
(0.06) \\
(0.22) \\
(0.50)\end{array}$ & $\begin{array}{r}0.25 \\
0.92 \\
-0.12 \\
0.44 \\
0.44 \\
0.68 \\
-0.26\end{array}$ & $\begin{array}{l}(0.02) \\
(0.04) \\
(0.03) \\
(0.00) \\
(0.02) \\
(0.01) \\
(0.08)\end{array}$ & 0.15 \\
\hline BM7 & $16 \mathrm{Aug}^{\mathrm{b}}$ & $\begin{array}{l}\text { Chla } \\
\text { Chl } c \\
\text { Zeaxanthin } \\
\text { Diadinoxanthin } \\
\text { Fucoxanthin } \\
\text { Alloxanthin } \\
\text { Peridinin }\end{array}$ & $\begin{array}{l}0.66 \\
0.77 \\
1.21 \\
1.25 \\
0.74 \\
0.01 \\
0.06\end{array}$ & $\begin{array}{l}\text { ND } \\
\text { ND } \\
N D \\
N D \\
N D \\
N D \\
N D\end{array}$ & $\begin{array}{r}0.19 \\
0.41 \\
0.24 \\
0.56 \\
0.20 \\
0.26 \\
-0.01\end{array}$ & $\begin{array}{l}\text { ND } \\
\text { ND } \\
N D \\
N D \\
N D \\
N D \\
N D\end{array}$ & 0.45 \\
\hline $\mathrm{HI}$ & 30 Oct & $\begin{array}{l}\text { Chl } a \\
\text { Chl } b \\
\text { Chl } c \\
\text { Fucoxanthin } \\
\text { Diadinoxanthin } \\
\text { Alloxanthin } \\
\text { Zeaxanthin } \\
\text { Peridinin }\end{array}$ & $\begin{array}{r}0.07 \\
0.12 \\
-0.12 \\
0.39 \\
0.18 \\
0.01 \\
0.64 \\
-0.56\end{array}$ & $\begin{array}{l}(0.08) \\
(0.22) \\
(0.03) \\
(0.05) \\
(0.11) \\
(0.06) \\
(0.25) \\
(0.15)\end{array}$ & $\begin{array}{r}0.17 \\
0.05 \\
-0.11 \\
0.22 \\
-0.16 \\
0.04 \\
0.75 \\
-0.49\end{array}$ & $\begin{array}{l}(0.04) \\
(0.08) \\
(0.05) \\
(0.03) \\
(0.03) \\
(0.04) \\
(0.02) \\
(0.03)\end{array}$ & 0.41 \\
\hline $\mathrm{HI}$ & $30 \mathrm{Oct}^{\mathrm{b}}$ & $\begin{array}{l}\text { Chl a } \\
\text { Chl b } \\
\text { Chl c } \\
\text { Fucoxanthin } \\
\text { Diadinoxanthin } \\
\text { Alloxanthin } \\
\text { Zeaxanthin } \\
\text { Peridinin }\end{array}$ & $\begin{array}{r}0.18 \\
0.19 \\
0.06 \\
0.33 \\
-0.12 \\
0.11 \\
0.25 \\
-0.57\end{array}$ & $\begin{array}{l}(0.34) \\
(0.28) \\
(0.28) \\
(0.27) \\
(0.33) \\
(0.47) \\
(0.17) \\
(0.35)\end{array}$ & $\begin{array}{r}0.18 \\
0.12 \\
0.01 \\
-0.02 \\
-0.28 \\
0.15 \\
0.45 \\
-0.37\end{array}$ & $\begin{array}{l}(0.02) \\
(0.04) \\
(0.03) \\
(0.01) \\
(0.00) \\
(0.01) \\
(0.00) \\
(0.03)\end{array}$ & 0.39 \\
\hline
\end{tabular}


some of the spatial and temporal pigment distributions we observed with what was known from previous microscopic studies of phytoplankton in the bay.

Based on chl $b$ concentration, chlorophytes were more significant in the upper bay, where the chl b:chl a ratio ranged as high as 0.20 in May. In the mid-bay this ratio never exceeded 0.03 . The higher concentrations of zeaxanthin in the upper bay in spring support earlier observations of the importance of filamentous cyanobacteria there (Sellner 1983), but the high amounts in the mid-bay in August suggest the importance of unicellular coccoid forms not quantified in earlier studies (cf. Ray et al. 1989, Malone et al. 1991). Peridinin abundance indicates that dinoflagellates were most important in summer and fall at the mid-bay station. Also in keeping with earlier studies, cryptophytes (as indicated by alloxanthin) had higher abundances in late spring through summer. Noteworthy is the high abundance of cryptophytes in October, a time when the phytoplankton is usually dominated by diatoms and dinoflagellates (Marshall \& Lacouture 1986)

Diatoms were an important component of the phytoplankton throughout the year at both stations. Assuming most of the fucoxanthin is associated with diatoms (some microflagellate groups also contain this pigment, though in lower abundance relative to $\mathrm{chl}$ a; Vesk \& Jeffrey 1977, Wright \& Jeffrey 1987), their contribution to the total phytoplankton biomass was maximal in spring.

Growth rates for the entire phytoplankton community (as chl a) ranged from $0.03 \mathrm{~d}^{-1}$ (April) to $0.41 \mathrm{~d}^{-1}$ (May) at the mid-bay station (mean $=0.23 \mathrm{~d}^{-1}$; Table 3). These growth rates are somewhat lower than those found in earlier studies. Using ${ }^{14} \mathrm{C}$ uptake to measure growth, Sellner \& Kachur (1987) estimated mean growth rates of $0.44 \mathrm{~d}^{-1}(\mathrm{SE}=0.03, \mathrm{n}=24$; converted to base e for comparison with our results) for summer/fall populations in the mid-bay region over a 6 yr study period. Malone et al. (1988), also using ${ }^{14} \mathrm{C}$. reported growth rates of 0.09 to $1.79 \mathrm{~d}^{-1}$ (mean $=0.56$, $\mathrm{SE}=0.19, \mathrm{n}=8$ ) for combined measurements made from February through October in the mid-bay region over several years. Both of these studies produced large data sets, averaged over months or years. Our small number of samples may not be representative of average growth rates in the bay over longer time scales. Also, we used only surface phytoplankton samples, which may have been photo-inhibited in summer. Departures from linearity in dilution curves can bias the estimate of growth rate, usually on the low side (Fig. 1). Because we used the '3-point' method of Gallegos (1989) to calculate growth rates, however, using only the data from the 2 most dilute treatments, we believe that non-linear feeding kinetics did not account for our measured low growth rates. More measurements will be needed to decide if the dilution method yields consistently lower phytoplankton growth rates in the bay.

Growth rates of some pigments were often substantially greater than those of chl a. For example, zeaxanthin growth rates were 3.8 and 9 times greater than those of chl a on 16 August and 30 October, respectively. Zeaxanthin growth rates exceeded those of chl a in 6 out of 6 determinations, suggesting a cyanobacterial population that is growing rapidly, even when it is not the biomass dominant. Fucoxanthin growth equalled or exceeded that of chl $a$ in 9 of 10 experiments, indicating that diatoms also were growing more rapidly than the phytoplankton as a whole. Overall, the great variability in growth rates among pigments supports the idea of heterogeneity in phytoplankton growth in situ and indicates that different factors (grazing, sinking, nutrients, etc.) regulate different phytoplankton groups in the bay.

Although some investigators have added nutrients to dilution bottles to prevent them from becoming depleted in the less dilute treatments, both Landry \& Hassett (1982) and Gifford (1988) reported that such additions can damage delicate microzooplankton. We did not routinely add nutrients, and we never observed the kind of dilution curve expected when nutrients are limiting differentially across the dilution gradient. If that were the case, the least dilute treatments would be expected to fall below the regression line. We usually saw the opposite. If anything, less dilute treatments were above the regression line (Fig. 1). The opposite concern, that phytoplankton relying on regenerated nutrients might grow more slowly in higher dilutions because the regenerators had been diluted out with the grazers, was not a problem in our experiments. Ammonium concentrations in the most dilute treatments always equalled or exceeded those in the undiluted treatments at the end of the incubation period (data not shown). In the 16 August experiment, a parallel dilution series with added nutrients showed higher growth at all dilutions, so that our growth rate estimate for chl a was 4 -fold higher. The dilution plots were parallel, however, so grazing rates were similar (Fig. 3, Table 3). The pattern of increased growth with added nutrients in that experiment held for all pigments except $c h l c$, which showed no difference, and alloxanthin, which decreased with added nutrients. In October, the effect of adding nutrients was less clear. For chl $a$, growth was increased $2.5 \times$ and grazing showed no change with added nutrients. For other pigments, results were mixed (Table 3 ). Only zeaxanthin growth showed a strong linear relationship with dilution, and it declined with added nutrients. Concerns about damage to microzooplankton caused by adding 


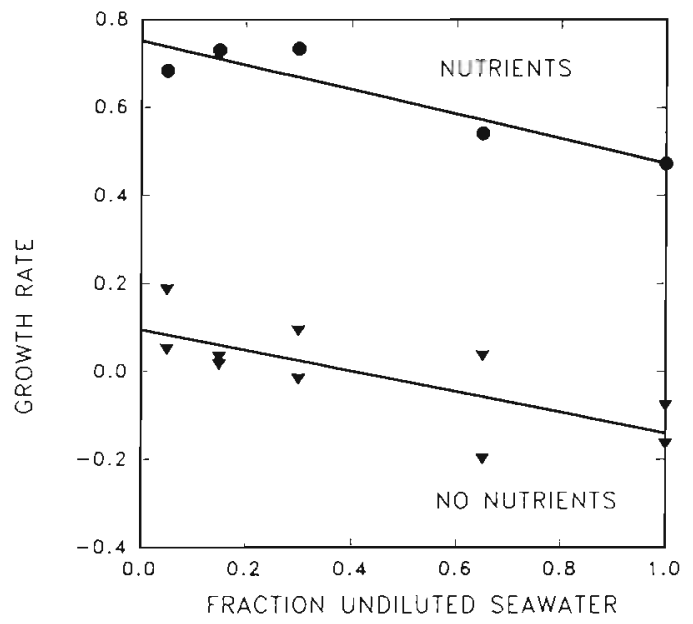

Fig. 3. Effect of nutrient addition on growth in the 16 August dilution experiment. $\mathrm{NH}_{4}{ }^{+}(5 \mu \mathrm{M})$ and $\mathrm{PO}_{4}{ }^{-3}(1 \mu \mathrm{M})$ were added to 5 of the bottles $(\bullet)$; the other 10 bottles were unsupplemented $(\mathbf{\nabla})$. Lines are least squares regressions, using all treatments

nutrients were not warranted. Ciliate growth in nutrient treatments equalled or exceeded that in unsupplemented treatments (Table 3 ).

As with previous studies, we found microzooplankton grazing to be a significant fraction of phytoplankton growth (cf. Burkhill et al. 1987, Gifford 1988, Strom \& Welschmeyer 1991). Our results are summarized in Fig. 4 for all pigments, experiments, and stations combined. A Bartlett's model II regression gave a slope of 0.57 (Sokal \& Rohlf 1969), indicating that across all

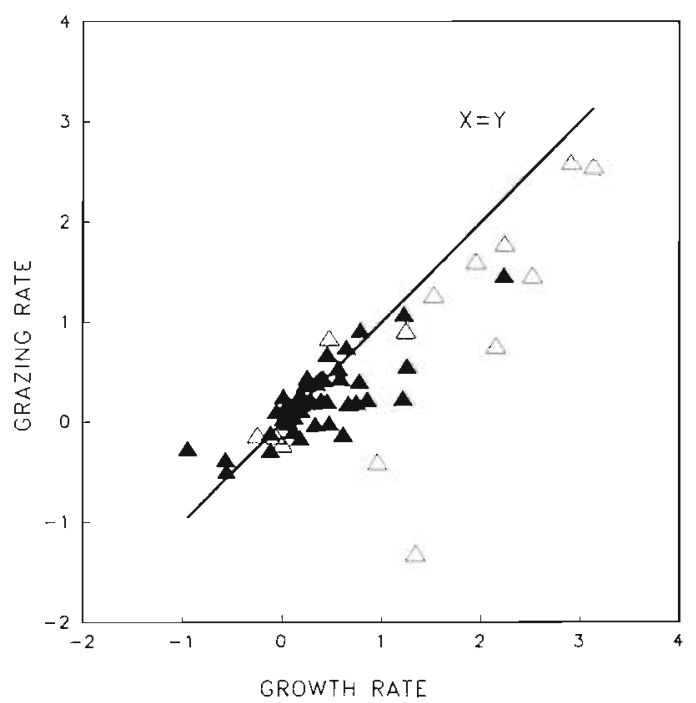

Fig. 4. Growth rate vs grazing rate for all pigments, all experiments. $(\Delta)$ Upper bay experiments; $(\Delta)$ mid-bay experiments. The line is for $x=y$; model II regression statistics for all data are: Grazing $=0.032+0.572$ Growth $(95 \%$ confidence interval for the slope: 0.27 to 1.03 ) phytoplankton taxa and sampling times more than half of the production is grazed by microzooplankton. Individual pigments showed some different trends. For example, grazing never exceeded growth for chl $b$ and diadinoxanthin (10 comparisons), but did so on 5 out of 7 experiments for alloxanthin, suggesting some selectivity in grazing by microzooplankton. Peridinin, which is characteristic of dinoflagellates, always gave us a negative grazing rate (net growth decreased with dilution; 5 of 5 experiments). Dinoflagellates are a diverse group, containing autotrophs, heterotrophs, and mixotrophs (phagotrophic forms that also contain photosynthetic pigments) as well as anomalously pigmented forms (Wilcox \& Wedemeyer 1985, Lessard 1991). Possibly, the mixotrophs grow more slowly when diluted because the loss of food is more important than release from predation. This explanation requires the mixotrophs to dominate phototrophic dinoflagellates, which presumably would respond to dilution like other phytoplankton. Data are not available to test this. Negative grazing for peridinin was not reported in 2 other studies that used the dilution technique with chemotaxonomic pigment markers (Burkhill et al. 1987, Strom \& Welschmeyer 1991), so its generality is questionable.

Grazing rarely exceeded growth at the upper bay station (2 out of 14 comparisons vs 20 out of 44 for the mid-bay). This suggests a downstream shift from more autotrophic to more heterotrophic plankton communities, a trend that has been documented for the lower bay and its coastal plume (Malone \& Ducklow 1990). An alternative explanation is that microzooplankton are less important grazers than macrozooplankton in the upper bay. However, although the composition of the zooplankton community changes downstream in the bay, with more rotifers and different dominant copepods in the upper bay, we know of no data indicating an increase in relative microzooplankton abundance down bay.

The dilution technique has been used to estimate microzooplankton grazing in a variety of environments, including tropical, temperate, and arctic regions (Landry et al. 1984, Burkhill et al. 1987, Paranjape 1987, Gifford 1988, Strom \& Welschmeyer 1991). Gallegos (1989) extended its usefulness to eutrophic waters, where phytoplankton may not always be growing under density dependent conditions, and it has now become a standard method. While it requires less manipulation of delicate microzooplankton than other incubation techniques (e.g. Capriulo 1982), and less time-consuming microscopy than surrogate particle techniques (e.g. Rublee \& Gallegos 1989), it still requires $24 \mathrm{~h}$ incubations of multiple treatments and thus yields data poorly resolved in space and time. In the present study, we 
used it to evaluate control of phytoplankton populations on seasonal time scales and across an estuarine salinity gradient ranging from nearly-fresh to mesohaline. We found a wide range of growth and grazing rates among phytoplankton taxa, suggesting both heterogeneity in what controls phytoplankton division rates and selectivity of grazers among taxa. In keeping with earlier studies (Burkhill et al. 1987, Gallegos 1989, Strom \& Welschmeyer 1991), we found growth and grazing to be closely coupled both within individual experiments (phytoplankton taxa that were growing rapidly were also grazed rapidly) and between seasons and stations (periods of rapid phytoplankton growth were also periods of rapid grazing). Although microzooplankton grazing accounted for 50 to $60 \%$ of the phytoplankton productivity on average, our observation that grazing was often saturated suggests that other factors (e.g. nutrient or light limitation) are also important in regulating phytoplankton biomass in the bay.

In common with a number of other studies, we have shown microzooplankton grazing to be an important sink for estuarine and coastal phytoplankton production (Capriulo \& Carpenter 1983, Gifford 1988). This is true even for diatom production, a significant fraction of which also exits the water column through passive sinking. For Chesapeake Bay, grazing serves to retain material in the water column, as mass of microzooplankters and their dissolved excretions, and probably results in higher production of copepods and other macrozooplankters that graze on microzooplankton.

Acknowledgements. We thank the crews of the 'Ridgely Warfield' and the 'Orion' for assistance at sea. Drs T Malone and $\mathrm{K}$. Sellner shared with us unpublished hydrographic and phytoplankton data. Drs R. Dawson and P. Sawangwong provided invaluable help with the pigment analyses, and Drs D. Gifford, S. Strom, and E. Lessard contributed helpful discussion. Ms C. Keefe helped with nutrient analyses. Dr K. Tenore and the Chesapeake Biological Laboratory provided laboratory space. This study was funded by Maryland Sea Grant (grant RDO-21 to GBM)

\section{LITERATURE CITED}

Boynton, W. R., Kemp, W. M., Keefe, C. W. (1982). A comparative analysis of nutrients and other factors influencing estuarine phytoplankton production. In: Kennedy, V. S. (ed.) Estuarine comparisons. Academic Press, New York, p. 69-90

Brownlee, D. C., Jacobs, F. (1987). Mesozooplankton and microzooplankton in the Chesapeake Bay. In: Majumdar, S. K. Hall, L. W. Jr, Austin, H. M. (eds.) Contaminant problems and management of living Chesapeake Bay resources. Pennsylvania Acad. Sci., Easton, p. 219-269

Burkhill, P. H., Mantoura, R. F. C., Llewellyn, C. A., Owens, N. J. P. (1987). Microzooplankton grazing and selectivity of phytoplankton in coastal waters. Mar. Biol. 93: 581-590
Capriulo, G. M. (1982). Feeding of field collected tintinnid micro-zooplankton on natural food. Mar. Biol. 71: 73-86

Capriulo, G. M., Carpenter, E. J. (1983). Abundance, species composition and feeding impact of tintinnid microzooplankton in central Long Island Sound. Mar. Ecol. Prog. Ser. 10: 277-288

Everitt, D. A., Wright, S. W., Volkman, J. K., Thomas, D. P., Lindstrom, D. P. (1990). Phytoplankton community compositions in the western equatorial Pacific determined from chlorophyll and carotenoid pigment distributions. Deep Sea Res. 37: 975-997

Gallegos, C. L. (1989). Microzooplankton grazing on phytoplankton in the Rhode River, Maryland: nonlinear feeding kinetics. Mar. Ecol. Prog. Ser. 57: 23-33

Gifford, D. J. (1988). Impact of grazing by microzooplankton in the Northwest arm of Halifax Harbour, Nova Scotia. Mar. Ecol. Prog. Ser. 47: 249-258

Goodrich, D. M., Boicourt, W. C., Hamilton, P., Pritchard, D. W. (1987). Wind-induced destratification in Chesapeake Bay. J. phys. Oceanogr. 17: 2232-2240

Jeffrey, S. W. (1980). Algal pigment systems. In: Falkowski, P. G. (ed.) Primary productivity in the sea. Plenum, New York, p. 33-58

Landry, M. R., Haas, L. W., Fagerness, V. L. (1984). Dynamics of microbial plankton communities: experiments in Kaneohe Bay, Hawaii. Mar. Ecol. Prog. Ser. 16: 127-133

Landry, M. R., Hassett, R. P. (1982). Estimating the grazing impact of marine microzooplankton. Mar. Biol. 67:283-288

Lessard, E. J. (1991). The trophic role of heterotrophic dinoflagellates in diverse marine environments. Mar. microb. Food Webs 5: 49-58

Malone, T. C., Crocker, L. H., Pike, S. E., Wendler, B. W. (1988). Influences of river flow on the dynamics of phytoplankton production in a partially stratified estuary. Mar. Ecol. Prog. Ser. 48: 235-249

Malone, T C., Ducklow, H. W. (1990). Microbial biomass in the coastal plume of the Chesapeake Bay: phytoplanktonbacterioplankton relationships. Limnol. Oceanogr. 35: 296-312

Malone, T. C., Ducklow, H. W., Peele, E. R., Pike, S. E. (1991). Picoplankton carbon flux in Chesapeake Bay. Mar. Ecol. Prog. Ser. 78: 11-22

Malone, T. C., Kemp, W. M., Ducklow, H. W., Boynton, W. R., Tuttle, J. H., Jonas, R. B. (1986). Lateral variation in the production and fate of phytoplankton in a partially stratified estuary. Mar. Ecol. Prog. Ser. 32: 149-160

Mantoura, R. F. C., Llewellyn, C. A. (1983). The rapid determination of algal chlorophyll and carotenoid pigments and their breakdown products in natural waters by reversephase high-performance liquid chromatography. Analyt. Chim. Acta 151: 297-314

Marshall, H. G., Lacouture, R. (1986). Seasonal patterns of growth and composition of phytoplankton in the lower Chesapeake Bay and vicinity. Estuar. coast. Shelf Sci. 23: $115-130$

McCarthy, J. J., Taylor, W. R., Loftus. M. E. (1974). Significance of nanoplankton in the Chesapeake Bay estuary and problems associated with the measurement of nanoplankton productivity. Mar. Biol. 24: 7-16

Nixon, S. W. (1987). Chesapeake Bay nutrient budgets - a reassessment. Biogeochem. 4: 77-90

Officer, C. B., Biggs, R. B., Taft, J. L., Cronin, L. E., Tyler, M., Boynton, W. R. (1984). Chesapeake Bay anoxia: origin, development, and significance. Science 223: 22-27

Paranjape, M. A. (1987). Grazing by microzooplankton in the eastern Canadian arctic in summer 1983. Mar. Ecol. Prog. Ser. 40: 239-246 
Parsons, T R., Maita, Y., Lalli, C. M. (1984). A manual of chemical and biological methods for seawater analysis Pergamon, New York

Ray, R. T., Haas, L. W., Sieracki, M. E. (1989). Autotrophic picoplankton dynamics in a Chesapeake Bay sub-estuary. Mar. Ecol. Prog. Ser. 52: 273-285

Roman, M. R., Ashton, K. A., Gauzens, A. L. (1988). Day/night differences in the grazing impact of marine copepods. Hydrobiol. 167/168:21-30

Rublee, P. A., Gallegos, C. L. (1989). Use of fluorescently labelled algae (FLA) to estimate microzooplankton grazing. Mar. Ecol. Prog. Ser. 51: 221- 227

Sellner, K. G. (1983). Plankton productivity and biomass in a tributary of the upper Chesapeake Bay. I. Importance of size-fractionated phytoplankton productivity, biomass and species composition in carbon export. Estuar. coast. Shelf Sci. 17: 197-206

Sellner, K. G., Kachur, M. E. (1987). Phytoplankton. In: Heck, K. L. Jr (ed.) Ecological studies in the middle reach of Chesapeake Bay. Springer-Verlag, Berlin, p. 12-37

Sokal, R. R., Rohlf, F. J. (1969). Biometry. W. H. Freeman, San Francisco

Strom, S. L., Welschmeyer, N. A. (1991). Pigment-specific rates of phytoplankton growth and microzooplankton grazing in the open subarctic Pacific Ocean. Limnol.

This article was presented by D. A. Caron. Woods Hole,

Massachusetts, USA
Oceanogr. 36: 50-63

Tuttle, J. H., Jonas, R. B., Malone, T. C. (1987). Origin, development and significance of Chesapeake Bay anoxia. In: Majumdar, S. K., Hall, L. W., Austin, H. M. (eds.) Contaminant problems and management of living Chesapeake Bay resources. Pennsylvania Acad. Sci., Easton, p. 442-472

Van Valkenburg, S. D., Jones, J. K., Heinle, D. R. (1978). A comparison by size class and volume of detritus versus phytoplankton in Chesapeake Bay. Estuar. coast. mar. Sci. 6: $569-582$

Vesk, M., Jeffrey, S. W. (1977). Effect of blue-green light on photosynthetic pigments and chloroplast structure in unicellular marine algae from six classes. J. Phycol. 13: $280-288$

Wilcox, L. W. Wedemeyer, G. J. (1985). Dinoflagellate with blue-green chloroplasts derived from an endosymbiotic eukaryote. Science 227: $192-194$

Wright, S. W., Jeffrey, S. W. (1987). Fucoxanthin pigment markers of marine phytoplankton analysed by HPLC and HPTLC. Mar. Ecol. Prog. Ser. 38: 259- 266

Wright, S. W., Shearer, J. D. (1984). Rapid extraction and high performance liquid chromatography of chlorophylls and carotenoids from marine phytoplankton. J. Chromatography 294: 281-295

Manuscript first received: March 13, 1992

Revised version accepted:August 18, 1992 